\title{
Effects of Caribbean sponge extracts on bacterial attachment
}

\author{
Sarah R. Kelly ${ }^{1}$, Paul R. Jensen ${ }^{2}$, Timothy P. Henkel ${ }^{1}$, William Fenical ${ }^{2}$, \\ Joseph R. Pawlik ${ }^{1, *}$
}

\begin{abstract}
${ }^{1}$ University of North Carolina at Wilmington, Center for Marine Science, Wilmington, North Carolina 28403, USA
${ }^{2}$ Center for Marine Biotechnology and Biomedicine, Scripps Institution of Oceanography, University of California, San Diego, La Jolla, California 92093, USA
\end{abstract}

\begin{abstract}
Attachment is one of the first steps in bacterial colonization. By inhibiting bacterial attachment on surface cells, sponges may not only prevent infection, but also the process of biofouling. Crude organic extracts from 26 species of Caribbean sponges were assayed for their ability to inhibit bacterial attachment. Bacterial attachment was tested using Vibrio harveyi, a motile marine bacterium, isolated from seawater collected above one of the reefs from which sponges were sampled. Extracts were incorporated into agar blocks at concentrations volumetrically equivalent to whole sponge tissue. Extracts from 21 of 26 species (81\%) resulted in bacterial attachment on treated blocks that was $<40 \%$ of attachment on controls. Of these extracts, 9 were particularly active, with mean levels of attachment $<8 \%$ of controls (Agelas conifera, Ailochroia crassa, Aka coralliphagum, Amphimedon compressa, Aplysina fulva, Erylus formosus, Plakortis halichondroides, Ptilocaulis spiculifera, Verongula gigantea). Extracts from 4 species (Ailochroia crassa, Chondrilla nucula, Ectyoplasia ferox, and Iotrochota birotulata) inhibited bacterial attachment in this assay but were not found to inhibit bacterial growth in a previous study. Purified compounds that deterred feeding of predatory fishes in a prior study were also tested for their effects on bacterial attachment; they were: oroidin, 4,5-dibromopyrrole-2-carboxylic acid and sceptrin from Agelas species, amphitoxin from A. compressa, aeroplysinin-1 and dibromocyclohexadienone from Aplysina species, steroidal glycosides from $E$. ferox, and formoside from E. formosus. Of these, all but the steroidal glycosides from E. ferox deterred bacterial attachment at natural concentrations, providing evidence that sponge secondary metabolites may have multiple ecological functions.
\end{abstract}

KEY WORDS: Epibiosis - Bacterial attachment - Antimicrobial $\cdot$ Chemical defense · Antifouling · Secondary metabolites

Resale or republication not permitted without written consent of the publisher

\section{INTRODUCTION}

The ecological roles of secondary metabolites found in marine sponges are beginning to be understood. Studies have demonstrated that sponge metabolites can function as defenses against predators (Pawlik et al. 1995, Chanas et al. 1996, Assmann et al. 2000, Kubanek et al. 2000), as allelopathic agents against competing organisms (Sullivan et al. 1983, Porter \& Targett 1988, Engel \& Pawlik 2000), and as antifoulants against settling larvae (Amade \& Chevolot
1982, Thompson et al. 1985, Davis et al. 1989, Pawlik 1993). Sponge secondary metabolites also frequently possess antimicrobial properties (Burkholder \& Ruetzler 1969, Berquist \& Bedford 1978, McCaffrey \& Endean 1985, Thompson et al. 1985, Amade et al. 1987, Becerro et al. 1994, Newbold et al. 1999) that may serve multiple ecological functions (Reiswig 1973, Paul 1992), including defenses against microbial pathogens.

It is likely that antimicrobial defenses have evolved in a wide range of marine organisms. Reiswig (1973) suggested that the production of antimicrobial 
metabolites by damaged sponges would be beneficial in preventing infection by pathogenic bacteria or fungi. Maximilien et al. (1998) provided evidence that the red algae Delisea pulchra chemically controls epibacterial abundances through the release of furanones. The production of antimicrobial secondary metabolites may also limit biofilm formation, and thereby provide an explanation for the relatively clean surfaces typically observed in benthic plants and invertebrates.

The formation of a bacterial biofilm is usually a prelude to the development of complex fouling communities (Mitchell \& Kirchman 1984, Steinberg et al. 2001). Bacterial colonization begins with primary attachment of motile bacteria to a surface. Bacterial attachment involves chemotaxis and reversible adsorption to a surface followed by permanent attachment with polymeric fibrils or pili. As bacteria continue to colonize a surface, cell growth occurs and cells increase in number to form small microcolonies (10 to 100 individual cells). Eventually, a matrix develops consisting of bacteria, detritus and organic molecules. This matrix conditions the surface for the attachment of unicellular and multicellular epibionts that may lead to the formation of a complex fouling community (Kirchman et al. 1982, Wahl 1989, Leitz \& Wagner 1993, Holmstrom \& Kjelleberg 1994).

Considering that most motile marine bacteria have chemoreceptors (Chet \& Mitchell 1976, Amsler \& Iken 2001), it is likely that bacteria respond to secondary metabolites adhered to, or exuded from, the surface cells of sponges. Sponges may chemically inhibit bacterial colonization, thereby preventing subsequent steps in the fouling process. For most sponges, the inhibition of fouling would be beneficial given the potential negative consequences of fouling such as feeding obstruction, tissue degradation, and the increased chance of dislodgement and mortality (Branch \& Griffiths 1988, Davis et al. 1989, Wahl 1989, Littler \& Littler 1995, Correra \& Sanchez 1996).

Antibacterial activity has been demonstrated for sponge extracts (e.g. Burkholder \& Ruetzler 1969, Amade \& Chevolot 1982, McCaffrey \& Endean 1985, Thompson et al. 1985, Newbold et al. 1999) using assays that detect the inhibition of bacterial growth or cell death. While these effects may prevent bacterial biofilm formation, sponge metabolites may also deter colonization through mechanisms that do not affect bacterial growth. For example, Wahl et al. (1994) and Maximilien et al. (1998) found that non-toxic concentrations of ascidian extracts and red algal compounds, respectively, strongly reduced the ability of bacteria to colonize a surface. Therefore, assays that measure bacterial responses to extracts or compounds may provide additional information about the ecologically relevant microbiological effects of marine natural products.

From an ecological standpoint, it is also important to test sponge extracts and compounds against bacteria that sponges would naturally encounter in the environment. Many previous studies of antimicrobial activity tested sponge metabolites against terrestrial or medically important strains (e.g. Burkholder \& Rutzler 1969, Berquist \& Bedford 1978, Amade \& Chevolot 1982, Amade et al. 1987). These assays are important in the search for novel antimicrobial agents, but metabolites may affect ecologically relevant marine bacteria in a different manner.

In this paper, we describe a method to test sponge extracts for their capacity to inhibit the attachment of a motile marine bacterium. The bacterium Vibrio harveyi was isolated from the same coral reef habitat from which the sponges were collected; strains of this bacterium are known to be opportunistically pathogenic for some marine fish and invertebrates (Lui et al. 1996, Alcaide et al. 2001). Crude organic extracts and purified compounds from sponges were assayed at concentrations that were volumetrically equivalent to those found in sponge tissues to determine their effects on bacterial attachment.

\section{MATERIALS AND METHODS}

Bacterial isolation. Bacteria were isolated from seawater samples obtained from Sweetings Cay, Bahamas $\left(26^{\circ} 33.721^{\prime} \mathrm{N}, 77^{\circ} 52.973^{\prime} \mathrm{W}\right)$, from 26 to 29 July 1999 , using standard plating techniques. Motile strains were identified by examining colony wet mounts with phase contrast microscopy $(1250 \times)$. The motile marine bacterium that was isolated and used in the attachment assay was identified as Vibrio harveyi by fatty acid methyl ester (FAME) analysis (similarity index of 0.95 ; Microbial ID, see www.midi-inc.com; using the Sherlock Microbial ID system). The strain of $V$. harveyi was maintained on YP media containing yeast extract (1 g $\left.\mathrm{l}^{-1}\right)$, peptone $\left(1 \mathrm{~g} \mathrm{l}^{-1}\right)$, agar $\left(16 \mathrm{~g} \mathrm{l}^{-1}\right)$ and seawater $(1 \mathrm{l})$. Bacteria were transferred from plate cultures to liquid YP medium, 12 to $20 \mathrm{~h}$ before assays were performed. Concentrations of liquid cultures were standardized by optical density (600 nm) before each assay using a Milton Roy Spectronic 20 D.

Sample collection and extraction. Tissue samples from 26 species of sponges were collected from coral reefs during 4 research expeditions: 2 in the Bahamas aboard RV 'Seward Johnson', in July/ August of 1999 and 2000, and 2 at the National Undersea Research Center in Key Largo, Florida, in October 1999 and May 2000. Collection sites in the Bahamas were Sweetings Cay $\left(26^{\circ} 33.721^{\prime} \mathrm{N}\right.$, 
$\left.77^{\circ} 52.973^{\prime} \mathrm{W}\right)$, Black Rock ( $\left.26^{\circ} 33.852^{\prime} \mathrm{N}, 77^{\circ} 41.374^{\prime} \mathrm{W}\right)$, Samana Cay $\left(23^{\circ} 23.380^{\prime} \mathrm{N}, 73^{\circ} 42.986^{\prime} \mathrm{W}\right)$, and Chub Cay $\left(25^{\circ} 01.509^{\prime} \mathrm{N}, 80^{\circ} 23.604^{\prime} \mathrm{W}\right)$. Collection sites in the Florida Keys were North Dry Rocks $\left(25^{\circ}\right.$ $\left.07.850^{\prime} \mathrm{N}, 080^{\circ} 17.521^{\prime} \mathrm{W}\right)$, Pickles Reef (24 $59.251^{\prime} \mathrm{N}$, $\left.080^{\circ} 24.64^{\prime} \mathrm{W}\right)$, Three Sisters $\left(25^{\circ} 01.340^{\prime} \mathrm{N}\right.$, $080^{\circ}$ $\left.26.327^{\prime} \mathrm{W}\right)$ and Conch Reef $\left(24^{\circ} 56.996^{\prime} \mathrm{N}, 080^{\circ}\right.$ 27.223' W). Samples were collected using SCUBA at depths between 3 and $30 \mathrm{~m}$. Samples were taken from the outer 2 to $4 \mathrm{~cm}$ of the sponge surface using a scalpel, leaving the remaining sponge for re-growth. Samples were immediately frozen $\left(-20^{\circ} \mathrm{C}\right)$ until ready for extraction.

Wet sponge tissue samples were thawed and cut into approximately $1 \mathrm{~cm}^{3}$ pieces and their volume quantified by solvent displacement in a graduated centrifuge tube. Pieces were added to $40 \mathrm{ml}$ of methanol until a final volume of $50 \mathrm{ml}$ was obtained. Samples were extracted in methanol for $24 \mathrm{~h}$. The resulting solution was filtered and the methanol removed by rotary evaporation using low heat $\left(<40^{\circ} \mathrm{C}\right)$. Samples were then extracted in 1:1 methanol:dichloromethane for an additional $24 \mathrm{~h}$. After filtration, the extracts were combined, transferred to scintillation vials, and dried under high vacuum. Crude extracts were stored under nitrogen at $-20^{\circ} \mathrm{C}$.

Attachment bioassay. The attachment assay was modified from one originally described by Wahl et al. (1994). Extracts were solubilized in 0.5 to $1.0 \mathrm{ml}$ acetone and then $10 \mathrm{ml}$ of molten YP medium $\left(60^{\circ} \mathrm{C}\right)$ was added and the vials swirled to mix the contents. The homogenous extract-agar mixtures were then pipetted into sterile petri dishes and allowed to cool. Control plates were prepared with solvent only. Five blocks, each with a $1 \mathrm{~cm}^{2}$ surface area and $\sim \mathrm{mm}$ thick, were cut with a sterile scalpel and removed from each extract-treated plate and placed in individual wells of 6 -well microtiter plates. Solvent only control blocks were added to plates in a similar manner.

Into each well of the microtiter plates, $3 \mathrm{ml}$ of autoclaved, filtered seawater and $25 \mu \mathrm{l}$ of bacterial culture was added. Bacterial cultures were grown overnight (12 to $18 \mathrm{~h}$ ) and cell concentrations standardized spectrophotometrically by diluting the media to an optical density of 0.27 . Blocks were exposed to the bacterial suspension for $1 \mathrm{~h}$, after which $30 \mu \mathrm{l}$ of $1 \mathrm{mg} \mathrm{ml}^{-1}$ DAPI (4', 6-diamidino-2-phenylindole) was added to stain the bacterial DNA. After $10 \mathrm{~min}, 300 \mu \mathrm{l}$ of $37 \%$ formaldehyde was added to fix the bacteria. Blocks were then immersed in a petri dish containing autoclaved, filtered seawater. The petri dish was swirled gently for $10 \mathrm{~s}$ to remove unattached bacteria from the blocks.

Control and extract-treated blocks were mounted on glass microscope slides, topped with cover slips, and examined with an Olympus BH-2 epifluorescence microscope (1250x) under ultraviolet excitation. Bacteria were quantified using epifluorescent direct count- ing (Kepner \& Pratt 1994). Five blocks (subsamples) were prepared for each extract and 10 random fields (each with an area of $0.64 \mathrm{~mm}^{2}$ ) were counted for each block, resulting in a total of 50 fields counted per extract. Bacterial counts on control blocks ranged from 50 to 300 , and counts on treated blocks were reported as a percentage thereof. The same bacterial cultures were used to assay the control and treatment blocks at the same time.

For each sponge species, replicate extracts were prepared from 3 to 5 individual sponges from geographically distant locations. Each replicate extract was assayed separately. The mean of the 50 counts from each replicate extract was compared to the associated control mean and the differences evaluated using the Permutation Test (Zar 1999). Bacterial attachment is presented as a percentage relative to control (Fig. 1) so that lower percentages reflect greater inhibition of bacterial attachment.

Purified compounds. Assays were also performed on purified compounds from Agelas spp., Amphimedon compressa, Aplysina spp., Ectyoplasia ferox and Erylus formosus. These compounds were previously isolated through bioassay guided fractionation in a study of antipredatory chemical defenses with a feeding assay using the bluehead wrasse Thalassoma bifasciatum (see a full description in Pawlik et al. 1995). Isolation procedures have been presented in detail for the bromopyrrole alkaloids oroidin and 4,5-dibromopyrrole2-carboxylic acid from Agelas clathrodes and sceptrin from Agelas conifera (Assmann et al. 2000), for the pyridinium alkaloid amphitoxin from Amphimedon compressa (Albrizio et al. 1995), for the bromotyrosine derivatives aeroplysinin-1 and dibromocyclohexadienone from Aplysina sp. (Puyana 2001), for the steroidal glycosides, including mixtures of ectyoplasides and feroxides from E. ferox (Kubanek et al. 2002), and for the triterpene glycosides, including formoside from E. formosus (Kubanek et al. 2000).

Serial dilutions of a crude extract from Amphimedon compressa and purified compounds from Agelas conifera, Amphimedon compressa, and Erylus formosus were tested to determine the lowest concentration at which attachment was inhibited. Dilutions were generated by combining the extract or purified compound $(10 \mathrm{ml}$ volumetric equivalents) with $10 \mathrm{ml}$ molten YP media and then diluting the mixture with YP media to obtain lower than natural concentrations.

\section{RESULTS}

Natural concentrations of crude organic extracts from 21 of 26 sponge species $(77 \%)$ significantly reduced bacterial attachment onto agar blocks relative 


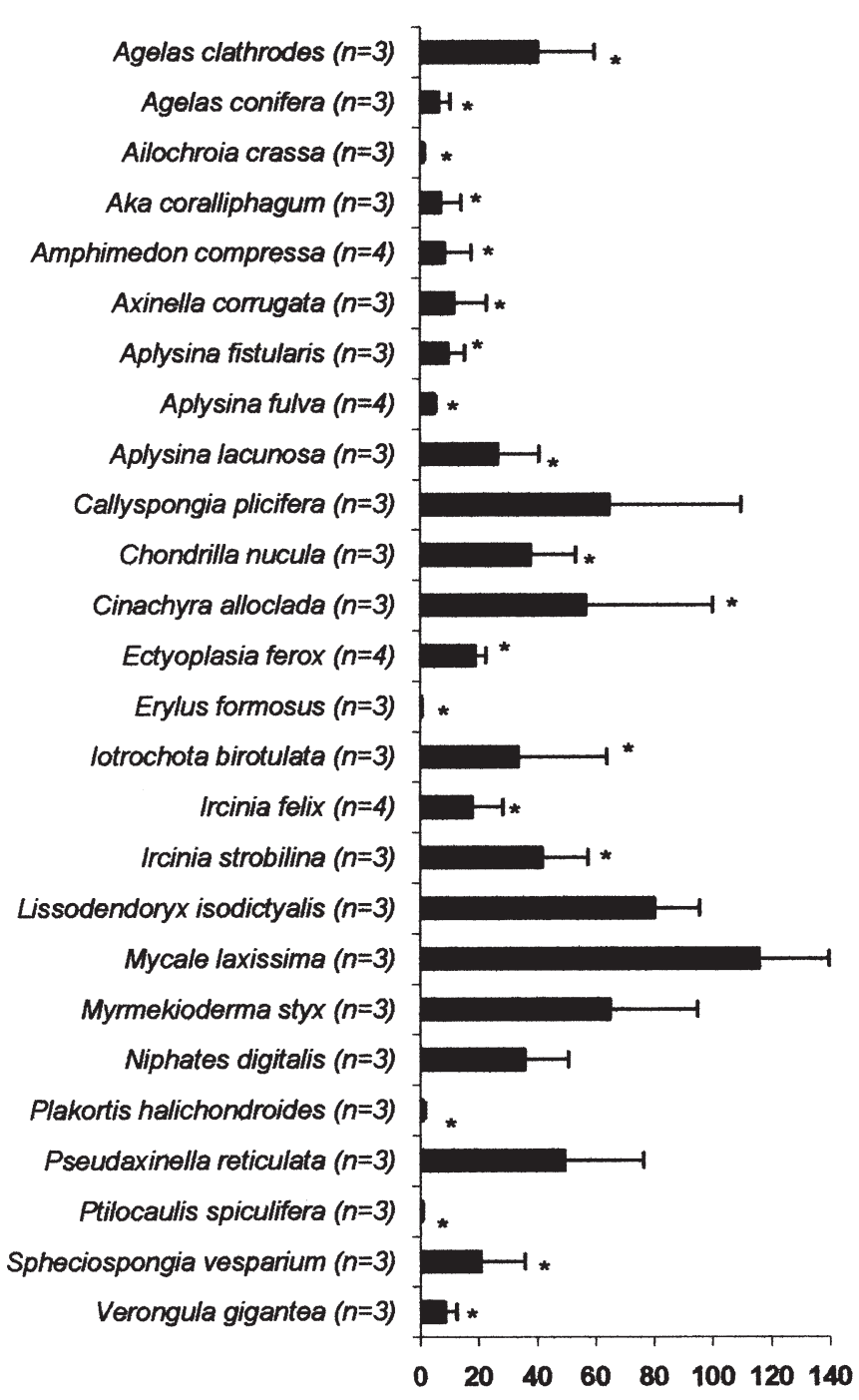

BACTERIAL ATTACHMENT (\%) RELATIVE TO CONTROL

Fig. 1. Vibrio harveyi. Percentage attachment on agar blocks containing volumetrically natural concentrations of crude extracts of sponges from Florida and the Bahamas. Data are expressed as \% attachment on control agar blocks. Mean \pm SE is shown for the number of replicate assays performed on extracts prepared from separate samples of sponge tissue, the number of which is shown after the name of each sponge. ${ }^{*}$ Significant difference from controls (permutation test)

to controls ( $\mathrm{p}<0.05$, Fig. 1). Extracts from 10 species were particularly active (Agelas conifera, Ailochroia crassa, Aka coralliphagum, Amphimedon compressa, Aplysina fistularis, Aplysina fulva, Erylus formosus, Plakortis halichondroides, Ptilocaulis spiculifera, and Verongula gigantea) with $\leq 10 \%$ bacterial attachment onto extract-treated blocks versus control blocks ( $p<0.001$, Fig. 1). Ten species (Agelas clathrodes, Aplysina lacunosa, Axinella corrugata, Chondrilla nucula, Ectyoplasia ferox, Iotrochota birotulata, Ircinia felix, I. strobilina, Spheciospongia vesparium) had 20 to $57 \%$ bacterial attachment compared to controls and were also significantly different than controls $(p<0.05)$. The crude extract of Mycale laxissima promoted attachment, with $16 \%$ more attachment on extract-treated blocks than control blocks.

The crude extracts of Agelas clathrodes and Agelas conifera deterred bacterial attachment at natural concentrations (Fig. 1, Table 1). Oroidin and 4,5-dibromopyrrole-2-carboxylic acid (Fig 2b,c) isolated from A. clathrodes and sceptrin isolated from A. conifera inhibited bacterial attachment at natural concentrations (Table 1). Sceptrin (Fig. 2a) also inhibited bacterial attachment at $50 \%$ of natural concentration. The crude extract of Amphimedon compressa deterred bacterial attachment at $3 \%$ of natural concentration while amphitoxin (Fig. 2d), purified from the same sponge species, was less active at this concentration (Fig. 3). The Aplysina species that were tested in this study all inhibited bacterial attachment (Fig. 1), and all 3 species contain dibromocyclohexadienone and aeroplysinin-1 (Fig. 2e,f) (Puyana 2001), both of which inhibit attachment at natural concentrations (Table 1). Isolated glycosides from Ectyoplasia ferox were not as inhibitory as the crude extract at natural concentrations (Table 1). The crude extract from Erylus formosus completely inhibited bacterial attachment at natural concentrations (Fig. 1), and formoside (Fig. 2g), a pure compound isolated from E. formosus, deterred attachment at natural concentrations and dilutions as low as $1 \%$ of natural concentration (Table 1 , data not shown).

Table 1. Bacterial attachment on agar blocks treated with crude sponge extracts and purified sponge metabolites. Percentage bacterial attachment is presented relative to attachment on control agar blocks. The approximate volumetric concentration of each metabolite from the sponge is given after each metabolite name, the same concentration used for the assay at natural concentration. Standard error is given for replicate assays ( $\mathrm{n}=3$ ). $\mathrm{BPC}=4,5$-dibromo-pyrrole-2-carboxylic acid, DIE = dibromocyclohexadienone. References to compound isolation can be found in the text

\begin{tabular}{|c|c|}
\hline $\begin{array}{l}\text { Extract and } \\
\text { purified compounds }\end{array}$ & $\begin{array}{c}\text { Bacterial } \\
\text { attachment }(\%)\end{array}$ \\
\hline Agelas clathrodes - crude & $40.3 \pm 19.4$ \\
\hline Oroidin $-0.8 \mathrm{mg} \mathrm{m}^{-1}$ & $30.3 \pm 0.6$ \\
\hline $\mathrm{BPC}-2.0 \mathrm{mg} \mathrm{ml}^{-1}$ & $35.1 \pm 0.5$ \\
\hline Oroidin + BPC & $12.0 \pm 0.2$ \\
\hline $\begin{array}{l}\text { Agelas conifera - crude } \\
\text { Sceptrin }-4.9 \mathrm{mg} \mathrm{ml}^{-1}\end{array}$ & $\begin{array}{l}6.3 \pm 3.9 \\
3.0 \pm 0.1\end{array}$ \\
\hline $\begin{array}{l}\text { Aplysina fulva - crude } \\
\text { Aeroplysinin- }-1.0 \mathrm{mg} \mathrm{ml}^{-1} \\
\text { DIE }-0.25 \mathrm{mg} \mathrm{ml}^{-1}\end{array}$ & $\begin{array}{l}4.9 \pm 0.5 \\
1.4 \pm 0.1 \\
4.1 \pm 0.1\end{array}$ \\
\hline $\begin{array}{l}\text { Ectyoplasia ferox-crude } \\
\text { Steroidal glycosides }-4.4 \mathrm{mg} \mathrm{ml}^{-1}\end{array}$ & $\begin{array}{l}44.3 \pm 0.4 \\
80.0 \pm 0.9\end{array}$ \\
\hline Erylus formosus - crude & $0.3 \pm 0.3$ \\
\hline Formoside & $16.6 \pm 0.2$ \\
\hline
\end{tabular}




\section{DISCUSSION}

The ubiquity of fouling organisms in the marine environment and the negative consequences of fouling are likely strong evolutionary pressures for marine organisms to develop defenses to protect their surfaces from fouling (Wahl 1989, Steinberg et al. 1997, Maximilien et al. 1998). One type of defense may be the production of secondary metabolites that prevent the initial steps in the bacterial fouling process, such as attachment, growth, and surface spreading (Steinberg et al. 1997, and references cited therein). In this study we examined the extent to which diverse Caribbean sponge extracts and purified compounds inhibit bacterial attachment.

While most studies investigating the microbiological effects of sponge extracts have focussed on detecting antibacterial activities, these activities are not necessarily correlated with the prevention of bacterial attachment. For example, Wahl et al. (1994) found that there was no correlation between epibacterial abundance on ascidian surfaces and extract antibiotic activity, while there was a correlation between bacterial abundance and effects on attachment. Maximilien et al. (1998) provided a detailed investigation of algal compounds (furanones) inhibiting the expression of specific bacterial characteristics such as swimming, attachment, growth, and surface spreading (via swarming). They concluded that not all furanones were active against all bacteria or all phenotypes (swimming, attachment, growth, and swarming), but the overall breadth and strength of inhibition observed suggested that these compounds were consistent inhibitors of bacterial colonization in the field. These authors concluded that investigations of the presence of bacterial chemical defenses in marine organisms should consider compound effects on specific stages of bacterial surface colonization.

Microbial chemical defenses in Caribbean sponges may be better understood by comparing our results from measurements of the inhibition of attachment with the results from other studies in which the effects on bacterial growth were tested. For example, Newbold et al. (1999) studied the effects of many of the same Caribbean sponge extracts on bacterial growth using a standard disc-diffusion assay. Of the 13 species

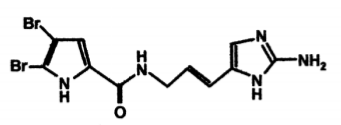

b

a<smiles>O=C1C=C([18O])NC1[18O]</smiles>

C
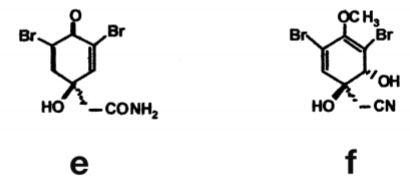

d

e

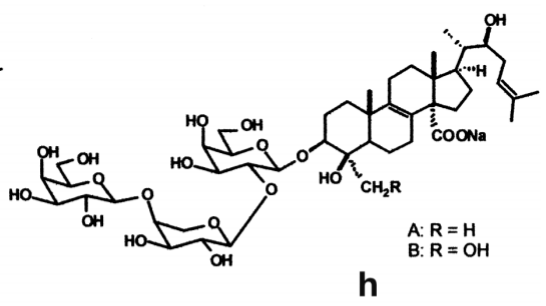

g

h

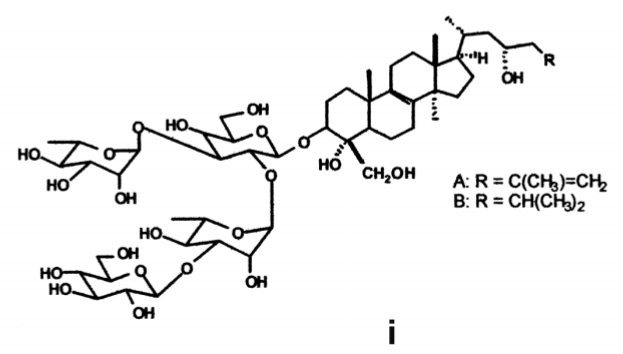

i

Fig. 2. Structures of (a) sceptrin, (b) oroidin, (c) 4,5-dibromopyrrole-2-carboxylic acid, (d) amphitoxin, (e) dibromocyclohexadienone, (f) aeroplysinin-1, (g) formoside, (h) ectyoplasides A and B, and (i) feroxosides A and B. References cited in text

that were tested in both studies, 6 significantly inhibited bacterial attachment but did not inhibit bacterial growth (Chondrilla nucula, Ectyoplasia ferox, Iotrochota birotulata, Niphates digitalis, Ailochroia crassa, and Pseudaxinella reticulata), suggesting that the mechanism of inhibition is not toxicity. These results provide further evidence that behavioral assays, which in this case measure the cumulative effects of toxicity, negative chemotaxis, and attachment inhibition, appear to be better predictors of antimicrobial chemical defenses than assays that measure only toxicity. Studies that address the physiological inhibition of bacterial attachment by sponge metabolites (i.e. through cell death or deterrence) could further elucidate the mechanism of antimicrobial chemical defense.

The production of antibacterial metabolites is not necessarily the only method for the control of bacterial colonization and surface fouling. The crude extract of Mycale laxissima enhanced bacterial attachment (Fig. 1), and did not inhibit bacterial growth (Newbold 


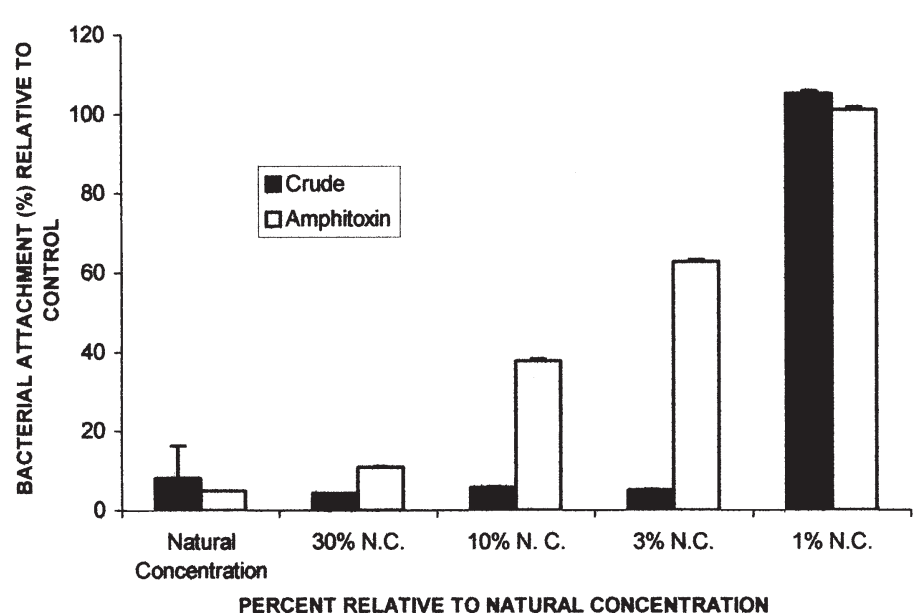

Fig. 3. Vibrio harveyi. Percentage attachment on agar blocks containing volumetrically natural concentrations (N.C.) of crude extracts of Amphimedon compressa or purified amphitoxin, and dilutions thereof. Data are expressed as \% attachment on control agar blocks. Mean $\pm \mathrm{SE}$ is shown for 5 subsamples of extract from 1 sponge and purified amphitoxin (data from 4 replicate extracts of $A$. compressa shown in Fig. 1)

et al. 1999). This sponge produces large amounts of mucus, and may use physical rather than chemical methods to control epibiosis. Similarly, the sponge Halichondria panicea regularly sloughs its outer cellular layer (Barthel \& Wolfrath 1989).

Whether sponge metabolites that inhibit bacterial attachment in laboratory assays using log-phase cultures grown in high-nutrient media also inhibit fouling in the field by ambient, low-density, starvation-phase bacteria will require further investigation. Moreover, it remains to be determined whether the concentrations of sponge metabolites to which bacteria are exposed in laboratory assays compare closely to those experienced in the field. However, laboratory assays with extracts and purified compounds from at least one species, Erylus formosus, correlated inhibition of bacterial attachment with the inhibition of propagule settlement in the field (Kubanek et al. 2002). Formoside, which accounts for $90 \%$ of the triterpene glycosides in E. formosus, deterred bacterial attachment at minimum concentrations of $3 \%$ of natural concentration and deterred fouling of gels in the field at natural concentrations. Kubanek et al. (2002) concluded that this inhibition of bacterial attachment might be responsible for retarding or excluding the settlement of propagules on gels containing compounds from E. formosus. Further evidence from the same study supported a correlation between inhibition of micro- and macrofouling by steroidal glycosides from Ectyoplasia ferox in both bacterial attachment assays and field macrofouling assays. In addition, Kubanek et al. (2002) analyzed the concentration and location of metabolites in the tissue of E. formosus and discovered that formoside was present on the surface of the sponge in concentrations that were inhibitory in the bacterial attachment and field assay. This combination of results suggests that $E$. formosus may reduce epibiotic fouling through the production of formoside. It remains to be determined whether or how metabolites are deployed on the surface of, or into the boundary layer of water surrounding, the other species of sponges used in the present study. An understanding of this critical component of sponge surface defenses remains elusive, and is likely variable for different taxa of sponges.

Three sponges from the genus Aplysina were tested in this study for their ability to inhibit bacterial attachment, A. fistularis, A. fulva, and A. lacunosa, and all 3 contain variable concentrations of dibromocyclohexadienone and aeroplysinin-1 (Puyana 2001), both of which inhibited bacterial attachment (Table 1). Previous studies have reported antibacterial activity of the brominated metabolites common to aplysinid sponges, but with assays using human pathogens and other terrestrial bacteria (Fattoruso et al. 1972, Moody et al. 1972, reviewed in Puyana 2001). The observation that these metabolites also inhibit marine bacteria indicates that they may play a role in antimicrobial chemical defense.

Purified amphitoxin inhibited bacterial attachment as effectively as the crude extract of Amphimedon compressa at natural concentrations, but the crude extract was more inhibitory than the purified metabolite at lower concentrations (Fig. 3). Previous studies have determined that extracts of $A$. compressa contain complex polymers of pyridinium alkaloids, including amphitoxin and halitoxin (Schmitz \& Gopichand 1978, Albrizio et al. 1995). Amphitoxin and halitoxin are known to be toxic to bacteria, invertebrates, and fish (Schmitz \& Gopichand 1978, Berlink et al. 1996). It may be that amphitoxin and halitoxin inhibit bacterial attachment in an additive or synergistic manner, which would explain the lower activity of purified amphitoxin at reduced concentrations compared to the crude extract.

The 3 brominated pyrrole alkaloids isolated from Agelas species deterred bacterial attachment at natural concentrations. Sceptrin was the most active of these compounds, inhibiting attachment at 50\% natural concentration. Assmann et al. (2000) determined that sceptrin was the dominant metabolite in $A$. conifera (68\% of the dimeric alkaloid fraction), while the predominant compounds in Agelas clathrodes were oroidin and 4,5-dibromopyrrole-2-carboxylic acid (Chanas et al. 1996, Assmann et al. 2000). The combination of oroidin and 4,5-dibromopyrrole-2-carboxylic acid inhibited attachment more than each compound tested individually, also suggesting an additive 
or synergistic effect. Previous studies have demonstrated that all 3 brominated pyrrole alkaloids deter fish predation (Chanas et al. 1996, Assmann et al. 2000). These metabolites may play an important role in the chemical defense of Agelas species by providing multiple defenses against predation, fouling, and bacterial pathogenesis.

The present study offers a useful survey of Caribbean sponge extracts for their capacity to deter the attachment of a ubiquitous marine bacterium. Such a survey can form the basis for subsequent bioassayguided isolation of the active metabolites. Pure metabolites used in the present study were not isolated in this manner, but had been isolated previously using a fish feeding inhibition assay; nevertheless, most of these metabolites also inhibited bacterial attachment (Table 1). It remains to be determined whether these metabolites are the only constituents of the crude extracts that deter bacterial attachment. In any case, the activity of all but one of these metabolites in both predation and bacterial attachment assays suggests that the secondary metabolites of some sponges have multiple ecological functions.

Acknowledgements. This research was made possible by grants from the NOAA/National Undersea Research Center at UNCW (NA 96RU-0260) and from the National Science Foundation, Biological Oceanography Program (OCE9711255, OCE-0095724). The study was conducted under National Marine Sanctuary Permit FKNMS-2001-021. Laura Rice and Craig Fairchild assisted with development of the assay technique. We are grateful to Michael Assmann, Sebastian Engel, Julia Kubanek, Monica Puyana, and Kristen Whalen for generously contributing purified sponge metabolites for assays. James Blum provided statistical advice. Thanks also to Greg McFall, Will O'Neal, and Dan Pisut for assistance with diving and collections.

\section{LITERATURE CITED}

Albrizio S, Ciminiello P, Fattorusso E, Magno S (1995) Amphitoxin, a new high molecular weight antifeedant pyridinium salt from the Caribbean sponge Amphimedon compressa. J Nat Prod 58:647-652

Alcaide E, Gil-Sanz C, Sanjuán E, Esteve D, Amaro C, Silveira L (2001) Vibrio harveyi causes disease in seahorse, Hippocampus sp. J Fish Dis 24:311-314

Amade P, Chevolot L (1982) Antimicrobial activities of marine sponges from French Polynesia and Brittany. Mar Biol 70: 223-228

Amade P, Cherroin C, Baby C, Vacelet J (1987) Antimicrobial activities of marine sponges from the Mediterranean sea. Mar Biol 94:271-275

Amsler CD, Iken KB (2001) Chemokinesis and chemotaxis in marine bacteria and algae. In: McClintock JB, Baker BJ (eds) Marine chemical ecology. CRC Press, Washington, DC, p 413-430

Assmann M, Lichte E, Pawlik JR, Kock M (2000) Chemical defenses of the Caribbean sponges Agelas wiedenmayeri and A. conifera. Mar Ecol Prog Ser 207:255-262
Barthel D, Wolfrath B (1989) Tissue sloughing in the sponge Halichondria panicea: a fouling organism prevents being fouled. Oecologia 78:357-60

Becerro MA, Lopez NI, Turon X, Uriz MJ (1994) Antimicrobial activity and surface bacterial film in marine sponges. J Exp Mar Biol Ecol 179:195-205

Berlink RGS, Ogawa CA, Almeida AMP, Sanchez MAA Malpezzi ELA, Costa LV, Hajdu E, de Freitas JC (1996) Chemical and pharmacological characterization of halitoxin from Amphimedon viridis (Porifera) from the southeastern Brazilian coast. Comp Biochem Physiol 115: 155-163

Berquist RP, Bedford JJ (1978) The incidence of antibacterial activity in marine Demospongiae: systematic and geographic considerations. Mar Biol 46:215-221

Branch GM, Griffiths CL (1988) The Benguela ecosystem. Part V. The coastal zone. Oceanogr Mar Biol Annu Rev 26: 395-486

Burkholder PR, Ruetzler K (1969) Antimicrobial activity of some marine sponges. Nature 222:983-4

Chanas B, Pawlik JR, Lindel T, Fenical W (1996) Chemical defense of the Caribbean sponge Agelas clathrodes (Schmidt). J Exp Mar Biol Ecol 208:185-196

Chet I, Mitchell R (1976) Ecological aspects of microbial chemoctactic behavior. Annu Rev Microbiol 30:221-339

Correra JA, Sanchez PA (1996) Ecological aspects of algal infectious diseases. Hydrobiologia 326/327:89-96

Davis AR, Targett NM, McConnell OJ, Young CM (1989) Epibiosis of marine algae and benthic invertebrates: natural products chemistry and other mechanisms inhibiting attachment and overgrowth. In: Scheuer PJ (ed) Bioorganic marine chemistry. Springer-Verlag, Berlin, p 85-114

Engel S, Pawlik JR (2000) Allelopathic activity of sponge extracts. Mar Ecol Prog Ser 207:273-281

Fattorusso E, Minale L, Sodano G (1972) Aeroplysinin-1, an antibacterial bromocompound from the sponge Verongia aerophoba. J Chem Soc Perkin Trans 1:16-18

Holmstrom C, Kjelleberg S (1994) The effect of external biological factors on attachment of marine invertebrate larvae and new antifouling technology. Biofouling 8:147-160

Kepner RL, Pratt JR (1994) Use of fluorochromes for direct enumeration of total bacteria in environmental samples: past and present. Microbiol Rev 58:60-615

Kirchman D, Graham S, Reisch D, Mitchell R (1982) Bacteria induce attachment and metamorphosis of Janua (Dexiospira) brasiliensis Grube (Polychaeta: Spirorbidae). J Exp Mar Biol Ecol 56:153-163

Kubanek J, Pawlik JR, Eve TM, Fenical W (2000) Triterpene glycosides defend the Caribbean reef sponge Erylus formosus from predatory fishes. Mar Ecol Prog Ser 207:69-77

Kubanek J, Whalen KE, Engel S, Kelly S, Henkel T, Pawlik JR (2002) Evidence for multiple defensive roles of triterpene glycosides in sponges. Oecologia 131:125-136

Leitz T, Wagner T (1993) The marine bacterium Altermonas espejiana induces metamorphosis of the hydroid Hydractinia echinata. Mar Biol 115:173-178

Littler MM, Littler DS (1995) Impact of CLOD pathogen on Pacific coral reefs. Science 267:1356-60

Lui PC, Lee KK, Chen SN (1996) Pathogenicity of different isolates of Vibrio harveyi in tiger prawn, Penaeus monodon. Lett Appl Microbiol 200:111-116

Maximilien R, de Nys R, Holmstrom C, Gram L, Givskov M, Crass K, Kjelleberg S, Steinberg PD (1998) Chemical mediation of bacterial surface colonization by secondary metabolites from the red alga Delisea pulchra. Aquat Microb Ecol 15:233-246

McCaffrey EJ, Endean R (1985) Antimicrobial activity of trop- 
ical and subtropical sponges. Mar Biol 89:1-8

Mitchell R, Kirchman D (1984) The microbial ecology of marine surfaces. In: Costlow JD, Tipper RC (eds) Marine biodeterioration: an interdisciplinary study. E\&FN Spon, London, p 49-58

Moody K, Thompson RH, Fattorusso E, Minale L, Sodano G (1972) Aerothionin and homoaerothionin: two tetrabromo spirocyclohexadienylisoxazoles from Verongia sponges. J Chem Soc Perkin Trans 1:18-24

Newbold RW, Jensen PR, Fenical W, Pawlik JR (1999) Antimicrobial activity of Caribbean sponge extracts. Aquat Microb Ecol 19(3):279-284

Paul VJ (1992) Chemical defenses of benthic marine invertebrates. In: Paul VJ (ed) Ecological roles of marine natural products. Cornell University Press, Ithaca, NY, p 164-188

Pawlik JR (1993) Marine invertebrate chemical defenses. Chem Rev 93:1911-1922

Pawlik JR, Chanas B, Toonen RJ, Fenical W (1995) Defenses of Caribbean sponges against predatory reef fish. I. Chemical deterrency. Mar Ecol Prog Ser 127:183-194

Porter JW, Targett NM (1988) Allelochemical interactions between sponges and corals. Biol Bull 175:230-239

Puyana M (2001) Chemical ecology of Caribbean sponges of the genus Aplysina. PhD thesis, University of California at San Diego

Reiswig HM (1973) Population dynamics of three Jamaician

Editorial responsibility: Kevin Carman,

Baton Rouge, Louisiana, USA
Demospongiae. Bull Mar Sci 23:191-226

Schmitz FJ, Gopichand Y (1978) (7E, 13, 15Z)-14,16-dibromo7,13,15-hexadecatrien-5-ynoic acid. A novel dibromoacetylenic acid from the marine sponge Xestospongia muta. Tetrahedron Lett 19 (39):3637-3640

Steinberg PD, Schneider R, Kjelleberg S (1997) Chemical defenses of seaweeds against microbial colonization. Biodegradation 8:211-220

Steinberg PD, de Nys R, Kjelleberg S (2001) Chemical mediation of surface colonization. In: McClintock JB, Baker BJ (eds) Marine chemical ecology. CRC Press, Washington, DC, p 355-388

Sullivan B, Faulkner DJ, Webb L (1983) Siphonodictidine, a metabolite of the burrowing sponge Siphonodictyon sp. that inhibits coral growth. Science 221:1175-1176

Thompson JE, Walker RP, Faulkner DJ (1985) Screening and bioassays for biologically-active substances from forty marine sponge species from San Diego, California, USA. Mar Biol 88:11-21

Wahl M (1989) Marine epibiosis. I. Fouling and antifouling: some basic aspects. Mar Ecol Prog Ser 58:175-189

Wahl M, Jensen PR, Fenical W (1994) Chemical control of bacterial epibiosis on ascidians. Mar Ecol Prog Ser 110: $45-57$

Zar JH (1999) Biostatistical analysis, 4th edn. Prentice-Hall, Upper Saddle River, NJ

Submitted: August 13, 2002; Accepted: December 22, 2002 Proofs received from author(s): February 16, 2003 